\title{
The cooling effect potential of urban river reserve in Johor, Malaysia
}

\author{
Siti Rahmah Omar ${ }^{1, *}$, Johan Sohaili ${ }^{1}$, and Nur Fadilah Darmansah ${ }^{2}$ \\ ${ }^{1}$ School of Civil Engineering, Universiti Teknologi Malaysia, 81310 Skudai, Johor, Malaysia \\ ${ }^{2}$ School of Biosciences and Medical Engineering, Universiti Teknologi Malaysia, 81310 Skudai, \\ Johor, Malaysia
}

\begin{abstract}
The Malaysian riparian buffer strip is also called the river reserve. As the state authority has the right to reserve state land for public purposes, there is high prospect to preserve green space in urban areas. Urban riparian, however, has been used only for bank stabilization, biodiversity, and water quality purposes. Prior studies verified that vegetated riparian minimises outdoor thermal condition, in comparison to impervious surface areas. Strategic distribution of green space and cooling sources in city planning are vital for maximum efficiency of green strategies. Hence, this paper determined the cooling effect potential of urban riparian structure on local thermal environment by investigating three river reserve areas. Thermal measurements were recorded at six locations perpendicular to the riverbank at $20 \mathrm{~m}$ intervals, along with a census of vegetation formation. Although the riparian zoning was located along the same river, different widths and various vegetation formations affected thermal distribution. The $\Delta \mathrm{T}_{\mathrm{i}}$ outcomes indicated that despite the small and restricted green space allocated in urban areas, the cooling effect was still present. Hence, green strategies must be carefully crafted to maximize use of space. The effects of urban riparian structure generate the multi-functions of urban river reserve, especially its cooling effect.
\end{abstract}

\section{Introduction}

The riparian buffer strip in Malaysia is also known as river reserve. The State Authority has been bestowed the rights to reserve state land for public purposes, including river reserves, as stipulated under Section 62 of the Malaysian National Land Code 1965. This enacted law is an excellent opportunity that aids in preserving the green space in an urban area. Although this beneficial urban green space has been only emphasized for riverbank stabilization, bio-diversity, and water quality purposes [1, 2], prior studies have verified that vegetated riparian reduces outdoor thermal condition when compared to impervious surface areas $[3,4]$. Vegetation has been proven to be an effective way to minimise urban temperatures [5] and the low evapotranspiration rate from the soil-vegetation system in urban areas is one of the major drivers that increase daytime temperatures [6]. The cooling effect of urban trees in a hot and humid climate is significant as it can contribute up to 3-4

\footnotetext{
* Corresponding author: ct.rahmah83@gmail.com
} 
degrees of cooling [7], while areas with mature trees gain more micro-climatic benefits than areas with merely small and young trees or grassy grounds [8]. Strategic distribution of green space in city planning, such as area width and cooling sources - forests or water bodies between areas, is essential to determine the efficiency of green strategies with increased cooling effect [9]. Hence, this paper looked into the cooling effect potential of urban riparian structure that modifies the local thermal environment.

\section{Methods}

This study was centred in Johor, Malaysia. Based on the variation of its riparian area that seems to be undisturbed by any human activity alongside the riverbank, Sungai Melana, as a representative of small-sized river located in the Johor Bahru district, had been selected for this study. After considering the aspects of land use, building orientation, and a clear river reserve boundary that allows accurate measurement, three river reserve areas located next to a housing area had been chosen (see Fig. 1). Surrounded by residential area, these three areas are undeveloped river reserve. The Taman Damai Jaya residency with its river reserve is labelled as Site A, while Taman Mutiara Rini area is Site B, and Taman Sri Pulai Perdana zoning area represents Site $\mathrm{C}$. These residential areas are located adjacent to the river reserve; have no obstruction between the areas, such as wastewater treatment plant; and accessible by foot.

Thermal measurements of ambient air temperature $\left({ }^{\circ} \mathrm{C}\right)$ was recorded for these three varied formations of river reserve and a census of vegetation formation was performed so as to assess the thermal effect upon the varied urban riparian settings. For each site, the thermal measurements were taken at six locations perpendicular to the riverbank at $20 \mathrm{~m}$ intervals. All measurement points were located at unshaded areas at the height of $1.2 \mathrm{~m}$ above the ground and data were recorded at every 30 minutes for 12 hours. The data for this thermal investigation were recorded between May 5 and May 21, 2017, from 6:00 until 18:00. The field measurements were taken on calm and clear weather by excluding rainy days. The outputs from the instrument were recorded and further analysed accordingly. Prior to the fieldwork, the instruments were calibrated depending on their conditions to ensure that the measurements taken were indeed accurate and unaffected due to faults. The measurements were carried out by using Lutron LM- 8000A, which refers to a 4-in-1 measuring instrument that is comprised of a temperature probe (Type $\mathrm{K}$ ) to measure temperature, an anemometer to measure air velocity, and a hygrometer to measure relative humidity. The Lutron LM-8000A can measure temperatures that range between -100 and $1300^{\circ} \mathrm{C}$ with an accuracy of $\pm\left(1 \% \mathrm{rdg}+1{ }^{\circ} \mathrm{C}\right)$.

In addition to the thermal investigation, an overview of the selected river reserve and their vegetation cover areas had been first observed via satellite imagery and later identified on-site. Subsequently, from the on-site observation, site zoning with an $80 \mathrm{~m}$-wide and $150 \mathrm{~m}$-length quadrat was demarcated perpendicular to the river, including the vegetated river reserve and nearby built-up areas. Covering an area of $12000 \mathrm{~m}^{2}$ respectively, all types of vegetation that grew in the quadrats were identified, including the coverage (\%) of vegetation-free and built-up areas [10,11, 12]. Vegetation was categorized into trees, shrubs, and grass $[13,14]$. The results retrieved from this study are illustrated in the form of representative diagram that portrays the proportions of green areas and river reserve zone [15]. Next, the findings were compared with the thermal measurements obtained from all the three sites. The variance in temperatures between the mean of maximum temperature and the temperature of specified points on site had been calculated using the following equation:

$$
\Delta T_{\mathrm{i}}=T_{\mathrm{i}}-T_{\mathrm{MaxR}}
$$


where $\mathrm{T}_{\text {MaxR }}$ refers to the mean of maximum temperature data gathered from the Malaysian Meteorological Department Station located at Senai, Johor; index i denotes the reference for the selected points; and the negative value of $\Delta \mathrm{T}_{\mathrm{i}}$ indicates cooling adjacent to the river, in comparison to the station reference.

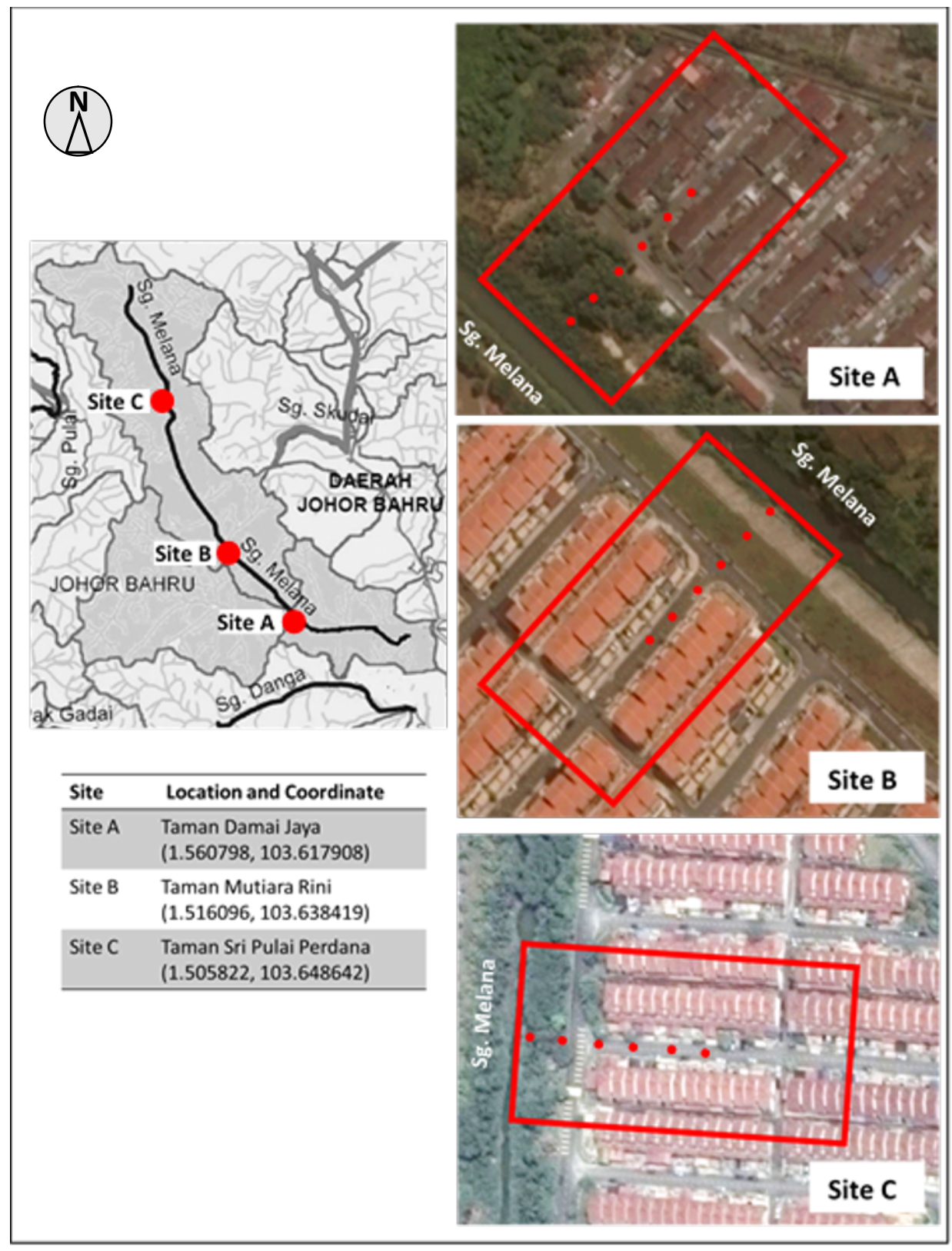

Fig. 1. The location of the surveyed river reserve along Sungai Melana. 


\section{Results and Discussion}

All sites were compared in terms of proportion of green area, vegetation formation, and proportion of sealed area. Site A appeared to have the widest riparian width at $55 \mathrm{~m}$ and the least build-up coverage area (see Table 1). Next, Sites B and C displayed 30m and 28m riparian width, respectively. Although the variance of riparian width between Sites B and C was only $2 \mathrm{~m}$ in length, Site $\mathrm{C}$ exhibited higher percentage of green area, when compared to that at Site B mainly due to housing and roadside greeneries. In fact, Site C displayed the highest percentage of area covered with trees, in comparison to the other sites.

Table 1. Riparian width and total coverage of green and build-up area.

\begin{tabular}{|c|c|c|c|c|c|c|}
\hline \multirow{2}{*}{ Site } & \multirow{2}{*}{$\begin{array}{c}\text { Riparian } \\
\text { Width }\end{array}$} & \multicolumn{4}{|c|}{ Green Area (\%) } & \multirow{2}{*}{$\begin{array}{l}\text { Build-up } \\
\text { Area (\%) }\end{array}$} \\
\hline & & Tree & Shrub & Grass & Total & \\
\hline $\mathbf{A}$ & $55 \mathrm{~m}$ & 7.89 & 37.08 & 1.50 & 46.47 & 53.53 \\
\hline B & $30 \mathrm{~m}$ & 0.15 & 3.40 & 12.27 & 15.82 & 84.18 \\
\hline $\mathbf{C}$ & $28 \mathrm{~m}$ & 14.27 & 15.43 & 10.02 & 39.72 & 60.28 \\
\hline
\end{tabular}

Site B displayed the highest percentage of build-up area at $84.18 \%$ and its riparian strip was dominated by grass that blanketed $12.27 \%$ of the whole zoning area, emerging as the highest grass area when compared to the other sites. Table 1 also shows that Site $\mathrm{C}$ had only half of the riparian width when compared to Site A with a difference of $27 \mathrm{~m}$, which can be considered as relatively small. For better comprehension regarding the green and build-up area coverages for all sites, the schematic diagram in Fig. 2 illustrates the proportions of green and river reserve zone. It was observed that even though all the selected riparian areas were located alongside the same river, varied widths were noted along with differing vegetation formations. This suggests that proper management and maintenance should be implemented based on the localities and the condition of each reserved area.

Furthermore, all sites were compared with $\Delta \mathrm{Ti}$, presented with the increasing distance from the centre of river measured perpendicularly to the bank (Fig. 3). During the study period, the average TMaxR value was $33^{\circ} \mathrm{C}$, which reflected the varied cooling factors for all three sites. The outcomes further displayed that Site A with the widest riparian width and the highest percentage of green surface area recorded the highest cooling effect amongst all sites. This had been expected as Site A had the least sealed surfaces. Meanwhile, Site B with the least overall green area coverage exemplified the highest diurnal temperature despite of its wider riparian width, in comparison to Site $\mathrm{C}$. This is mainly due to the lacking of trees noted in Site B, where limited shading was observed to shelter the area from direct solar radiation, thus causing higher ambient air temperature. Nevertheless, despite the high air temperature recorded in Site B, Fig. 3 shows that the temperature was at its lowest at the riverbanks nearby water bodies. This may result from the high atmospheric moisture content due to evapotranspiration derived from the soilvegetation system and the river water.

The $\Delta \mathrm{Ti}$ results for Site $\mathrm{C}$ indicated that although the green space allocated in urban areas had been small and restricted, the cooling effect was still present as long as the potential of green strategies is identified and embedded throughout the zoning area after considering all the influential factors, apart from maximizing the best use of each space. Nonetheless, the wild and unkempt vegetation in Sites A and C resulted in wind blockage due to low wind speed in the urban riparian area (see Fig. 4). Even when compared to Site 
B, the lack of shrubs and trees in Site B caused less friction in the riparian area, thus the wind speed was relatively higher throughout the diurnal hours.

The findings indicated that despite of the existence of urban riparian is mostly covered by wild vegetation with improper maintenance, its impact upon micro-climate had been quite substantial. Although the measurements were recorded at unshaded areas, surfaces covered by greeneries did exert an impact on the air temperature. Although wind from the green areas is known to reduce the temperature in built-up area, this study showed that unmanaged urban riparian caused wind blockage, which affected its surrounding ventilation. Even if the built-up area showed high wind speed (see Fig. 4, Site C), high convection over sealed surface did not have any impact upon air temperature as evaporative surfaces did. Hence, wind blockage and ventilation should be further investigated since beneficial cooling sources such as vegetated riparian and water bodies between the areas are deemed as necessary to determine the efficiency of green strategy in urban area. This contributes to the local authority and other practitioners so as to elaborate a more substantial urban river reserve maintenance and management.

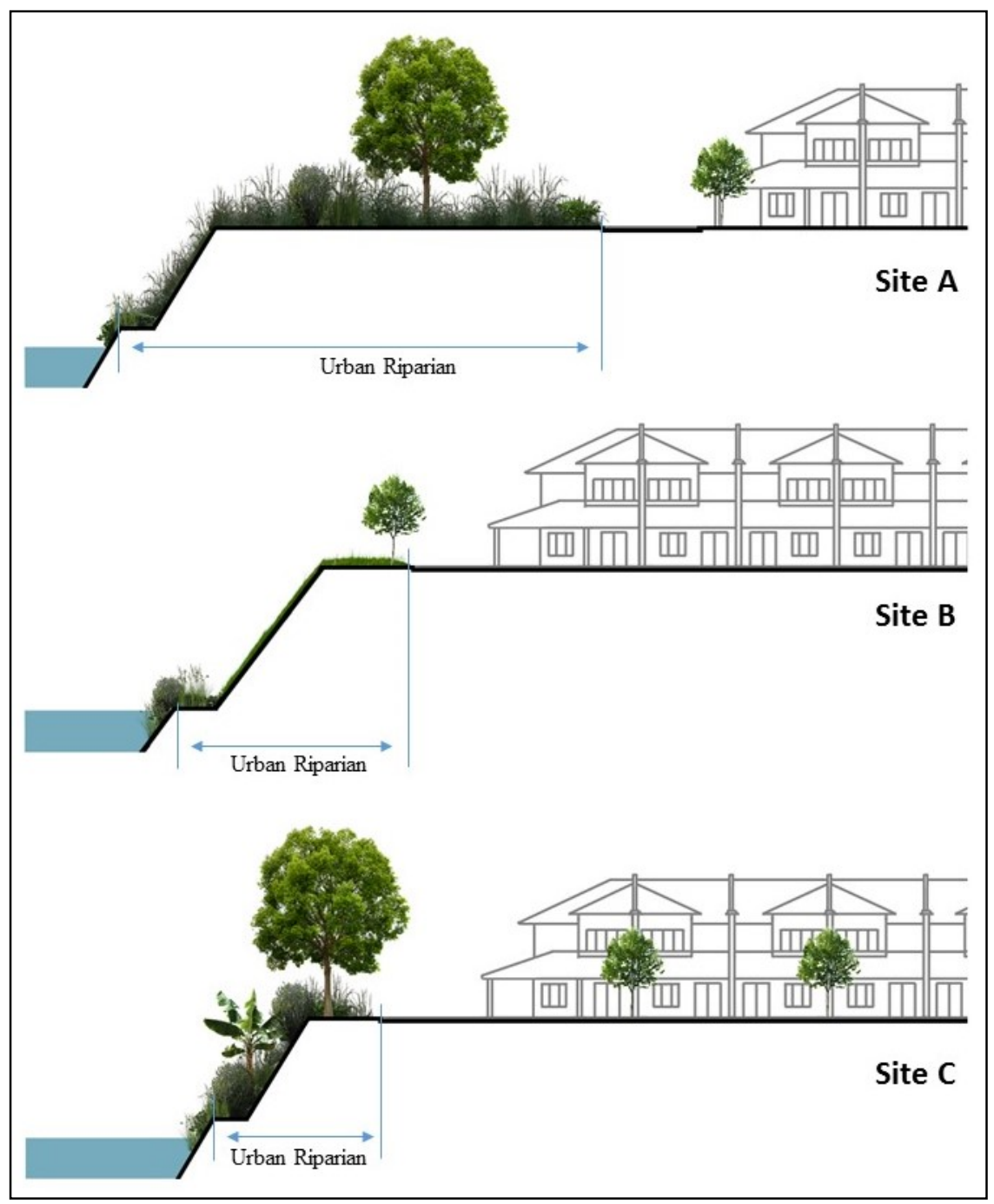

Fig. 2. The proportions of green and riparian areas for all sites. 


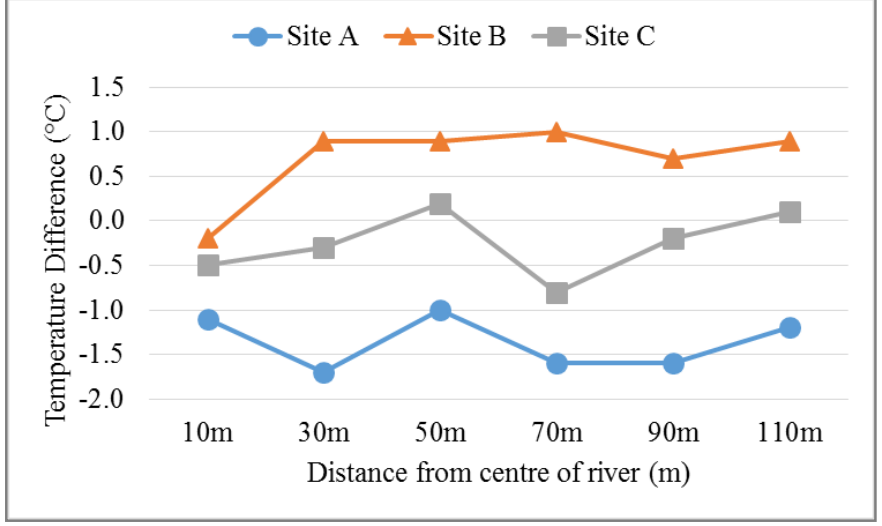

Fig. 3. Values of $\Delta T_{i}$ moving away from the river at all sites.

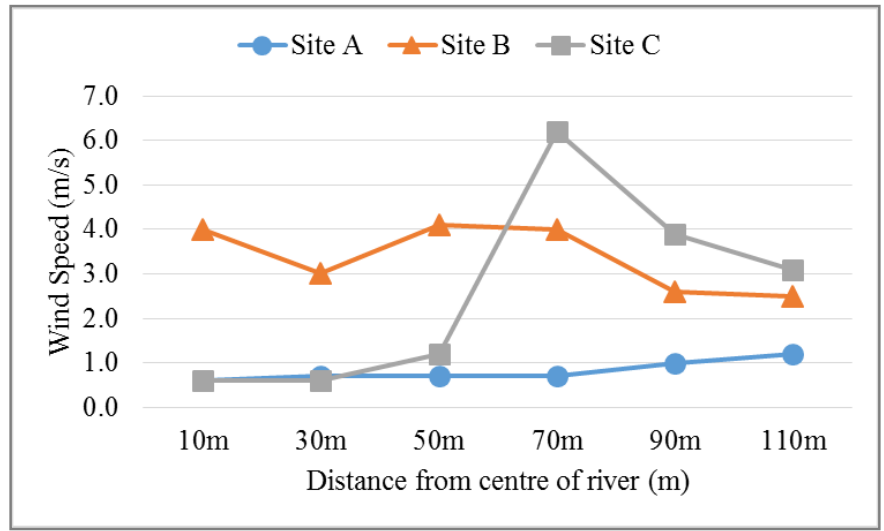

Fig. 4. Average wind speed value moving away from the river for all sites.

\section{Conclusion}

Reserved land and water bodies are indeed necessary to serve as green strategies amidst urban areas. Urban river reserve does have the potential as a passive cooling instrument that benefits its nearby surrounding. By understanding the basic vegetation requirements for urban river buffer, its functions can be maximized to meet all outlined objectives, aside from reaping micro-climatic benefits. Additionally, viable and effective management and maintenance should be designed to suit each area and its localities as no one solution fits all. All micro-climatic aspects that are specific for hot and humid climate must be weighed in without simply adapting blind strategies intended for other types of climate. Therefore, the effect of urban riparian structure has to be thoroughly investigated so as to determine the multi-functions of urban river reserve, particularly its cooling effect potential within its surrounding areas and nearby residences as well.

The authors would like to express their appreciation to Zamalah UTM for providing scholarship to the first author. 


\section{References}

1. Department of Irrigation and Drainage Malaysia, Garis Panduan Pembangunan Melibatkan Sungai Rezab Sungai (Department of Irrigation and Drainage (DID) Malaysia, Kuala Lumpur, Malaysia, 2012).

2. Department of Irrigation and Drainage Malaysia, Urban Stormwater Management Manual for Malaysia MSMA, 2ndEdition ed. (Department of Irrigation and Drainage (DID) Malaysia, Kuala Lumpur, Malaysia, 2012).

3. E. A. Hathway and S. Sharples, Build. Environ. 58, 14 (2012).

4. C. W. Tsai, T. Young, P. H. Warren, and L. Maltby, Appl. Geogr. 87, 106 (2017).

5. D. E. Bowler, L. Buyung-Ali, T. M. Knight, and A. S. Pullin, Landsc. Urban Plan. 97, 147 (2010).

6. H. Taha, Energy Build. 25, 99 (1997).

7. L. Shashua-Bar, O. Potchter, A. Bitan, D. Boltansky, and Y. Yaakov, Int. J. Climatol. 30, 44 (2010).

8. A. Y. Davis, J. Jung, B. C. Pijanowski, and E. S. Minor, Appl. Geogr. 71, 106 (2016).

9. T. Kubota, H. S. Lee, A. R. Trihamdani, T. T. T. Phuong, T. Tanaka, and K. Matsuo, Sustain. Cities Soc. 32, 295 (2017).

10. C. B. Koc, P. Osmond, and A. Peters, Procedia Eng. 169, 183 (2016).

11. J. Park, J.-H. Kim, D. K. Lee, C. Y. Park, and S. G. Jeong, Urban For. Urban Green. 21, 203 (2017).

12. I. Lehmann, J. Mathey, S. Rößler, A. Bräuer, and V. Goldberg, Ecol. Indic. 42, 58 (2014).

13. E. Edwards, Bothalia 14, 705 (1983).

14. Ministry of Natural Resources and Environment, Managing Biodiversity in the Riparian Zone (Ministry of Natural Resources and Environment (NRE) Malaysia, 2009).

15. S. Asakawa, K. Yoshida, and K. Yabe, Landsc. Urban Plan. 68, 167 (2004). 